\title{
Kajian pengembangan imbal jasa lingkungan di daerah aliran sungai (DAS) Kampar
}

\author{
M. Yunus ${ }^{1 *}$, A. Haryanto ${ }^{2}$ \\ ${ }^{1}$ Perkumpulan Alam Zamrud, Kabupaten Kampar, Riau, Indonesia \\ 2WWF Indonesia, Jakarta, Indonesia
}

\begin{abstract}
Abstrak.
Kajian ini bertujuan menjajaki pengembangan imbal jasa lingkungan di daerah aliran sungai (DAS) Kampar. Objek yang dikaji adalah nilai keinginan membayar (Willingness to Pay/WTP) dan nilai keinginan menerima (Willingness to Accept/WTA). Subjek dalam kajian ini adalah pelanggan PLN dan PDAM Tirta Kampar. Nilai WTP pelanggan PLN sebesar Rp895.462.286 per bulan atau sekitar Rp10.745.547.432 per tahun. Sementara nilai WTP pelanggan PDAM sebesar Rp16.919.039 per bulan atau sekitar Rp203.028.472 per tahun. Nilai WTP total adalah sebesar Rp10.948.575.904 per tahun. Nilai WTA responden adalah Rp5.900/pohon/tahun. Nilai WTP pemanfaat air sebesar Rp10.948.575.904 per tahun dapat digunakan untuk kegiatan konservasi secara vegetatif dan sipil teknis.
\end{abstract}

Kata kunci: imbal jasa lingkungan, daerah tangkapan air, WTP, WTA

\begin{abstract}
.
This study aims to explore the development of payment for environmental services in the Kampar river basin. The object of the study is the willingness to pay (WTP) and willingness to accept (WTA). The subjects in this study were PLN customers and PDAM Tirta Kampar customers. PLN customer's WTP value of Rp895,462,286 per month or around Rp10,745,547,432 per year. While the PDAM customer's WTP value is Rp16,919,039 per month or around Rp203,028,472 per year. The total WTP value is Rp10,948,575,904 per year. Respondent's WTA value is Rp5,900/tree/year. The WTP value of water users is Rp10,948,575,904 per year can be used for vegetative and technical civil conservation activities.
\end{abstract}

Keywords: payment for environmental services, catchment area, WTP, WTA

\section{PENDAHULUAN}

Pemanfaatan sumber daya air pada daerah aliran sungai (DAS) Kampar di satu sisi terus meningkat. Padahal di sisi lain, ketersediaan sumber daya air semakin terbatas. Apabila hal seperti ini tidak diantisipasi, maka dikhawatirkan dapat menimbulkan ketegangan dan bahkan konflik akibat benturan kepentingan. Selain itu, kerusakan daerah tangkapan air akan mempengaruhi kuantitas dan kualitas air yang diterima. Kondisi ini akan semakin menurun apabila tidak didukung oleh usaha untuk melakukan perbaikan terhadap kondisi sumber air yaitu dengan melakukan konservasi daerah tangkapan air.

Upaya konservasi daerah tangkapan air Sungai Kampar sangat penting dilakukan demi menjamin keberlanjutan sumber air. Ketersediaan air (di hilir) sangat terkait dengan kondisi sumber air (di hulu), sehingga terganggunya fungsi hidrologis wilayah tangkapan air di daerah hulu akan mengakibatkan terganggunya ketersediaan air di hilir.

Kerusakan lahan dan kawasan resapan air yang semakin meningkat telah meningkatkan kerentanan pasokan air bagi masyarakat. Kondisi ini diperparah dengan ketidakcukupan dana untuk melindungi dan merehabilitasi air di kawasan resapannya. Dengan semakin mendesaknya upaya konservasi daerah

\footnotetext{
${ }^{*}$ Korespondensi Penulis

Email : mohd.yoenoes@gmail.com
}

JPLB, 3(3):389-402, 2019 
tangkapan air, maka keperluan dana konservasi juga mendesak, baik yang bersumber dari pemerintah maupun dari pemanfaat jasa lingkungan air. Nilai keinginan membayar secara agregat atau total terhadap konservasi daerah tangkapan air dari pemanfaat jasa lingkungan air (pembangkit listrik, air minum, air produksi dan lain sebagainya) dapat dijadikan suatu alternatif untuk pendanaan konservasi.

Pendanaan konservasi merupakan salah satu bentuk tanggung jawab pemanfaat air untuk membantu mendanai kegiatan konservasi daerah tangkapan air yang selama ini memasok kebutuhan airnya (Grizetti et al. 2016). Pendanaan konservasi dapat diketahui dengan menjajaki nilai keinginan membayar dan kesanggupan untuk menyediakan dana tersebut dari pemanfaat jasa lingkungan air. Tujuan utama kajian ini adalah menjajaki pengembangan imbal jasa lingkungan (IJL) di DAS Kampar. Tujuan utama tersebut dicapai melalui serangkaian tujuan antara yaitu menghitung nilai keinginan membayar (Willingness to Pay/WTP) pemanfaat air, menghitung nilai potensial yang dihasilkan melalui mekanisme IJL, menghitung biaya konservasi daerah tangkapan air, mengetahui persepsi masyarakat terhadap program IJL dan menghitung nilai WTA (Willingness to Accept/WTA) masyarakat terhadap program IJL.

\section{METODOLOGI}

\subsection{Lokasi kajian dan waktu penelitian}

Lokasi kajian berada di dua provinsi yaitu di Provinsi Riau dan Provinsi Sumatera Barat yang sebagian besar merupakan daerah tangkapan air bagi Sungai Kampar (Gambar 1). Hasil kajian Kusuma (2018) menyatakan bahwa daerah ini memiliki nilai jasa lingkungan yang potensial. Lokasi kajian di Provinsi Riau dikhususkan untuk mengumpulkan data keinginan membayar (Willingness to Pay/WTP) yaitu dari pelanggan PLN di Kota Pekanbaru dan pelanggan PDAM Tirta Kampar di Kabupaten Kampar. Lokasi kajian di Provinsi Sumatera Barat dikhususkan untuk mengumpulkan data keinginan menerima (Willingness to Accept/WTA) di Kabupaten Lima Puluh Kota. Kajian ini dilaksanakan pada tanggal 24 Februari-1 Maret 2019 di Provinsi Riau dan tanggal 4-10 Maret 2019 di Provinsi Sumatera Barat.

\subsection{Prosedur pengumpulan dan analisis data}

Objek yang diteliti pada kajian ini adalah nilai keinginan membayar (WTP) pemanfaat jasa lingkungan air dan nilai keinginan menerima (WTA) penyedia jasa lingkungan air. Subjek dalam kajian ini meliputi pelanggan PLN dan PDAM serta pengelola PLN dan PDAM tersebut. Dalam kajian ini, sampel untuk mengetahui nilai WTP adalah pelanggan PLN (200 sampel) dan PDAM Tirta 
Kampar (100 sampel), dengan teknik penentuan sampel yang digunakan adalah simple random sampling. Sampel yang diambil dari pengelola PLN dan PDAM Tirta Kampar terdiri dari informan kunci yaitu pada level top management dan personal/staf teknis yang menangani dan memahami hal-hal terkait.

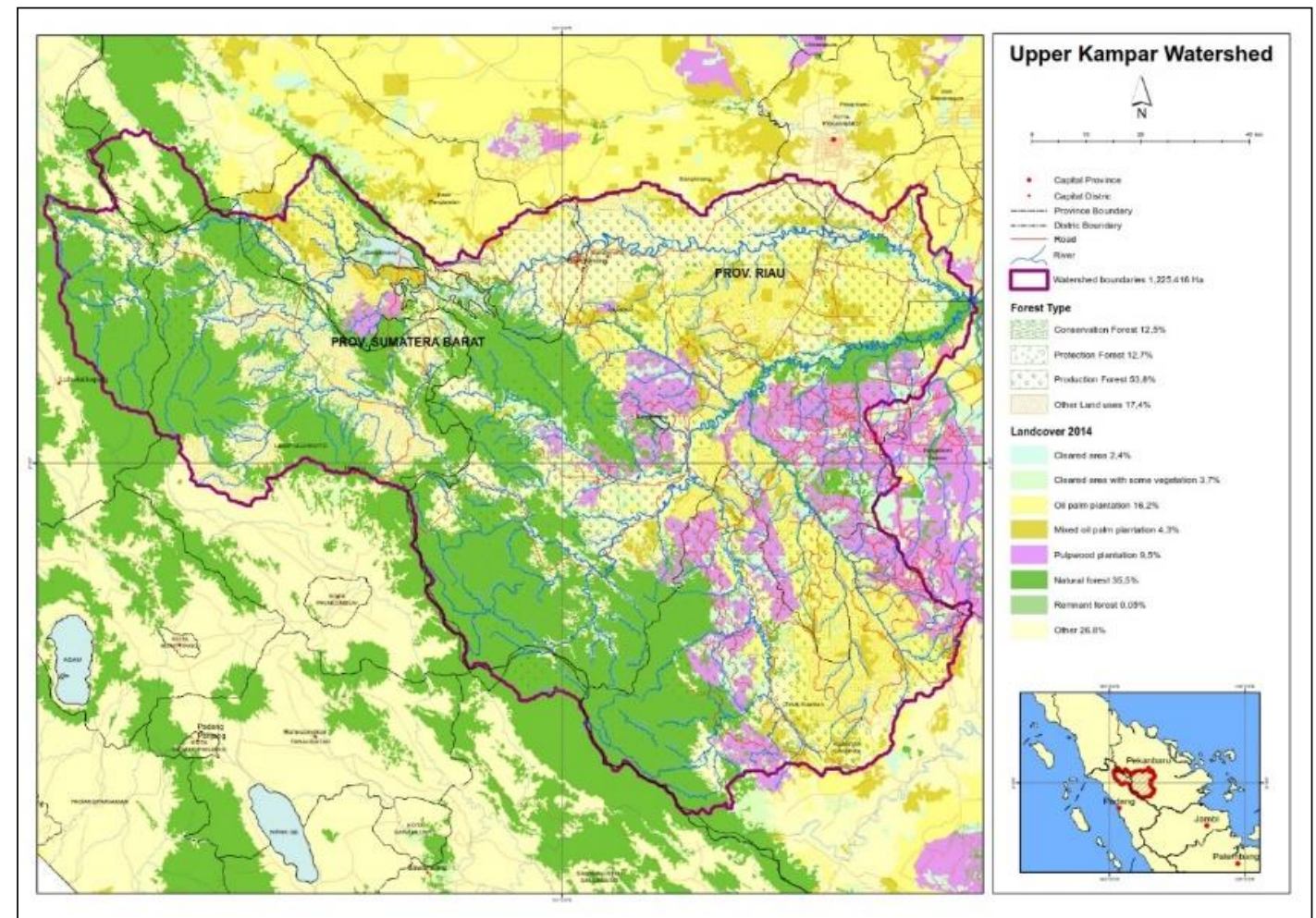

Gambar 1. Lokasi kajian pengembangan imbal jasa lingkungan di DAS Kampar.

Parameter-parameter yang dikaji adalah keinginan membayar (WTP) terhadap konservasi daerah tangkapan air menggunakan pendekatan contingent valuation method (CVM). Metode valuasi ini adalah perhitungan secara langsung dengan menanyakan keinginan membayar (WTP) kepada responden/pelanggan (Pour et al. 2012). Hal lain yang juga dikumpulkan dan dianalisis adalah data karakteristik sosial ekonomi responden yang meliputi umur, jenis kelamin, jumlah tanggungan keluarga, pendapatan, pendidikan, pemakaian air, pengetahuan tentang konservasi daerah tangkapan air, persepsi tentang konservasi daerah tangkapan air, sikap terhadap upaya konservasi daerah tangkapan air, pandangan tentang tanggung jawab biaya konservasi dan persepsi tentang kuantitas air. Parameter lain yang dikaji adalah biaya konservasi daerah tangkapan air dan estimasi WTA sebagaimana disajikan pada Tabel 1. 
Tabel 1. Parameter, indikator, subjek, metode dan analisis data.

\begin{tabular}{|c|c|c|c|c|c|}
\hline No & Parameter & Indikator & Subjek & $\begin{array}{l}\text { Metode } \\
\text { pengumpulan data }\end{array}$ & Analisis data \\
\hline 1 & $\begin{array}{l}\text { Keinginan } \\
\text { membayar } \\
\text { (WTP) } \\
\text { pelanggan PLN } \\
\text { dan PDAM }\end{array}$ & $\begin{array}{l}\text { Nilai keinginan } \\
\text { membayar/Nilai } \\
\text { WTP }\end{array}$ & $\begin{array}{l}\text { Pelanggan PLN } \\
\text { dan PDAM }\end{array}$ & $\begin{array}{l}\text { Kuesioner kepada } \\
\text { responden PLN dan } \\
\text { PDAM }\end{array}$ & $\begin{array}{l}\text { Analisis WTP } \\
\text { dengan } \\
\text { metode CVM }\end{array}$ \\
\hline 2 & $\begin{array}{l}\text { Nilai potensial } \\
\text { yang dihasilkan } \\
\text { melalui } \\
\text { mekanisme IJL }\end{array}$ & Nilai Total WTP & $\begin{array}{l}\text { Pelanggan PLN } \\
\text { dan PDAM }\end{array}$ & $\begin{array}{l}\text { Kuesioner kepada } \\
\text { responden PLN dan } \\
\text { PDAM }\end{array}$ & $\begin{array}{l}\text { Analisis } \\
\text { deskriptif }\end{array}$ \\
\hline 3 & $\begin{array}{l}\text { Biaya konservasi } \\
\text { daerah } \\
\text { tangkapan air }\end{array}$ & $\begin{array}{l}\text { Biaya untuk } \\
\text { kegiatan } \\
\text { konservasi, } \\
\text { rehabilitasi dan } \\
\text { restorasi daerah } \\
\text { tangkapan air }\end{array}$ & $\begin{array}{l}\text { Kelompok tani, } \\
\text { BPDAS HL, } \\
\text { DLHK dan } \\
\text { instansi terkait }\end{array}$ & $\begin{array}{l}\text { - Wawancara semi } \\
\text { terstruktur } \\
\text { - Data Sekunder }\end{array}$ & $\begin{array}{l}\text { Analisis } \\
\text { deskriptif }\end{array}$ \\
\hline 4 & $\begin{array}{l}\text { Persepsi } \\
\text { masyarakat } \\
\text { terhadap } \\
\text { program IJL }\end{array}$ & $\begin{array}{l}\text { Pengetahuan dan } \\
\text { persepsi } \\
\text { masyarakat } \\
\text { terhadap IJL }\end{array}$ & Kelompok tani & $\begin{array}{l}\text { Kuesioner kepada } \\
\text { responden petani }\end{array}$ & $\begin{array}{l}\text { Analisis } \\
\text { deskriptif }\end{array}$ \\
\hline 5 & $\begin{array}{l}\text { Estimasi nilai } \\
\text { WTA masyarakat } \\
\text { terhadap } \\
\text { program IJL }\end{array}$ & $\begin{array}{l}\text { Nilai keinginan } \\
\text { menerima/Nilai } \\
\text { WTA }\end{array}$ & Kelompok tani & $\begin{array}{l}\text { Kuesioner kepada } \\
\text { responden petani }\end{array}$ & $\begin{array}{l}\text { Analisis } \\
\text { WTA dengan } \\
\text { metode CVM }\end{array}$ \\
\hline
\end{tabular}

\section{HASIL DAN PEMBAHASAN}

\subsection{Gambaran umum wilayah kajian}

Sungai Kampar berhulu di pegunungan Bukit Barisan, mengalir ke arah timur dan bermuara di Selat Malaka. Sungai Kampar melintasi dua provinsi, sebagian berada di wilayah Provinsi Riau dan sebagian di Provinsi Sumatera Barat. Secara geografis, Sungai Kampar terletak antara 100,138-103,356 BT dan 0,585 LS-0,725 LU. Sungai Kampar Kanan bermata air dari Gunung Gadang yang memiliki luas daerah tangkapan air sebesar $\pm 5.231 \mathrm{~km}^{2}$. Alur utama semula mengalir ke utara kemudian berbelok ke timur, bertemu dengan anak Sungai Kapur nan Gadang mengalir dengan kemiringan sedang melalui lembah Batu Bersurat, kemudian bertemu dengan anak Sungai Mahat mengalir ke arah timur.

Kapasitas aliran penampang Sungai Kampar Kanan di sekitar Bangkinang berkisar antara 750-1.000 m³/detik dengan kemiringan dasar sekitar 0,0008, antara Danau Bingkuang dan Teratak Buluh sekitar 700-800 $\mathrm{m}^{3} /$ detik dengan kemiringan dasar sekitar 0,00021 (BWSS III 2007). Sungai Kapur nan Gadang 
dan Batang Mahat bertemu menjadi satu di hulu Koto Panjang. Sungai Kampar Kanan terdiri dari 24 anak sungai.

Sungai Kampar saat ini dimanfaatkan untuk berbagai penggunaan antara lain untuk keperluan transportasi, irigasi pertanian, perikanan, domestik (masyarakat), air baku air minum dan industri. Luas daerah irigasi di DAS Kampar total sebesar 22.213 ha, daerah rawa seluas 35.000 ha, dengan air baku sebesar 75,9 $\mathrm{m}^{3} /$ detik (debit minimum 124,8 $\mathrm{m}^{3} /$ detik dan maintenance flow $48,9 \mathrm{~m}^{3} /$ detik) (Kementerian PUPR 2015).

\subsection{Pengetahuan, persepsi dan sikap responden terhadap konservasi daerah tangkapan air}

Pengetahuan, persepsi dan sikap responden terhadap konservasi daerah tangkapan air merupakan variabel yang diteliti dalam kajian ini selain variabel karakteristik sosial ekonomi pelanggan yang diduga mempengaruhi keinginan membayar terhadap konservasi daerah tangkapan air. Sebanyak 200 responden pelanggan PLN dan 100 responden pelanggan PDAM diikutsertakan dalam kajian ini. Berdasarkan hasil kajian, ditemukan bahwa sebagian besar responden tidak mengetahui mengenai konservasi daerah tangkapan air (Gambar 2).

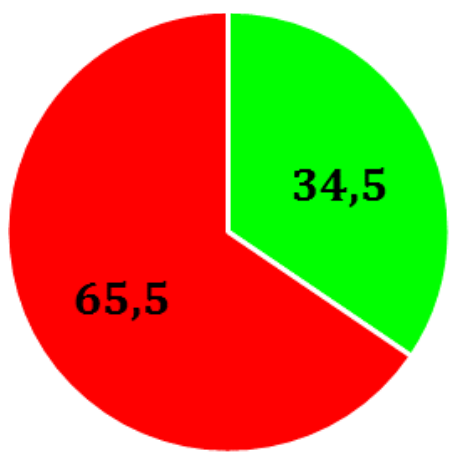

(a)

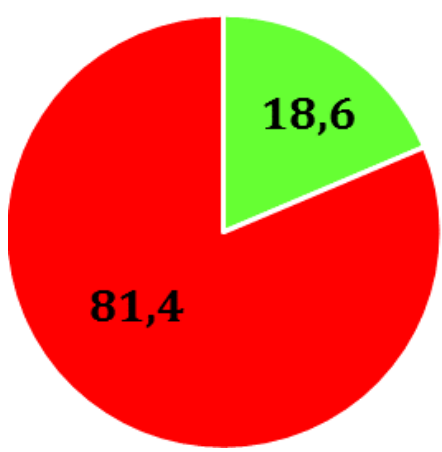

(b)

- : Tidak mengetahui istilah dan tujuan konservasi air

- : Mengetahui istilah dan tujuan konservasi air

Gambar 2. Persentase pengetahuan responden tentang konservasi daerah tangkapan air ( $a=$ pelanggan PLN; $b=$ pelanggan PDAM).

Sebanyak 34,5\% responden PLN menyatakan mengetahui mengenai istilah dan tujuan konservasi daerah tangkapan air, sedangkan 65,5\% responden menyatakan tidak mengetahui. Sementara untuk pelanggan PDAM, sebanyak $18,6 \%$ responden menyatakan mengetahui mengenai istilah dan tujuan konservasi daerah tangkapan air, sedangkan $81,4 \%$ responden menyatakan tidak mengetahui. Pengetahuan tersebut sebagian besar diperoleh dari internet, koran/media cetak, televisi dan sosialisasi dari dinas dan lembaga terkait. 
Responden menyatakan bahwa tujuan melakukan konservasi daerah tangkapan air adalah untuk mempertahankan dan melestarikan daerah tangkapan air, untuk menyelamatkan lingkungan, untuk kelangsungan hidup dan untuk menjaga ketersediaan air di wilayahnya. Kesediaan membayar menurut Fauzi (2010) adalah peubah tak bebas yang tergantung pada faktor sosial, ekonomi, budaya dan persepsi masyarakat terhadap perbaikan lingkungan. Pendapatan, pekerjaan, umur, jenis kelamin, pengetahuan tentang lingkungan, persepsi terhadap perubahan lingkungan dan partisipasi atau konsumsi bisa berpengaruh terhadap kesediaan membayar.

Responden dari pelanggan PLN maupun PDAM hampir secara keseluruhan memiliki persepsi positif terhadap pentingnya upaya konservasi daerah tangkapan air (Gambar 3). Sebanyak 98,6\% responden pelanggan PLN menyatakan bahwa penting untuk dilakukannya konservasi daerah tangkapan air, sedangkan 1,4\% responden menyatakan sebaliknya karena ketidaktahuan. Sementara untuk pelanggan PDAM juga menunjukkan hal serupa, sebanyak 98,7\% responden menyatakan penting dan 1,3\% menyatakan tidak penting karena ketidaktahuan.

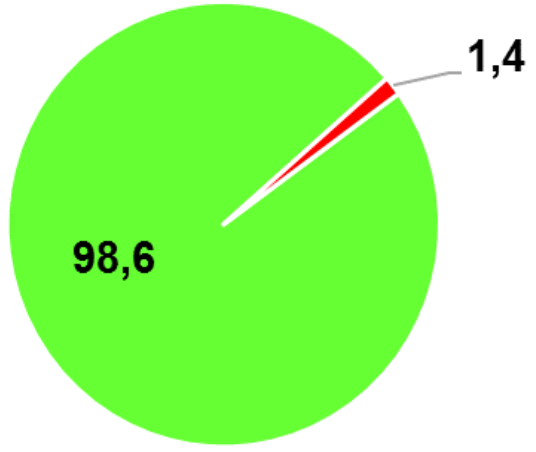

(a)

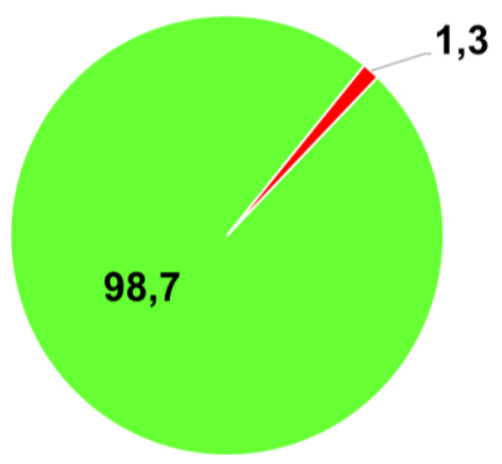

(b)

- $\quad$ : $\quad$ Tidak penting
$\quad \quad$ Penting

Gambar 3. Persentase persepsi responden mengenai pentingnya upaya konservasi daerah tangkapan air ( $a=$ pelanggan PLN; b=pelanggan PDAM).

Ketidaktahuan responden yang dimaksudkan adalah dikarenakan belum pernah mendengar istilah, tujuan dan manfaat konservasi daerah tangkapan air. Walaupun demikian, ada juga sebagian responden yang menyatakan penting meskipun belum pernah mendengar istilah, tujuan dan manfaat konservasi daerah tangkapan air. Hal tersebut dinyatakan oleh responden karena telah merasakan manfaat secara langsung dengan adanya ketersediaan air yang mencukupi untuk kebutuhan mereka. Adapun responden yang mengetahui tentang manfaat konservasi daerah tangkapan air menyatakan bahwa 
manfaatnya adalah untuk meningkatkan kualitas dan kuantitas air yang lebih baik, agar air dapat mengalir terus menerus, agar distribusi air merata dan kebutuhan akan air dapat terpenuhi secara berkesinambungan.

Sikap responden terhadap upaya konservasi daerah tangkapan air merupakan persetujuan responden terhadap upaya konservasi. Sebagian besar responden, baik PLN maupun PDAM menyatakan sikap setuju terhadap upaya konservasi daerah tangkapan air. Umumnya sebelum seseorang bersikap terhadap suatu objek, akan didahului oleh persepsi terhadap objek tersebut (Fripp 2014). Apabila persepsi terhadap sesuatu baik maka sikap seseorang terhadap suatu objek tersebut akan baik pula.

Persepsi tentang kuantitas dan kualitas air adalah penilaian responden PDAM terhadap kuantitas dan kualitas air yang diterima. Penilaian ini akan mempengaruhi kepuasan responden terhadap air. Kuantitas air dilihat dari penilaian responden tentang cukup atau tidak cukupnya air yang diterima. Sebanyak 98\% responden PDAM menyatakan bahwa kuantitas air yang diterima adalah cukup dan hanya $2 \%$ responden yang menyatakan kuantitas air yang diterima tidak cukup.

Kualitas air dilihat dari penilaian responden PDAM tentang keadaan air yang dapat dilihat, dirasa dan dibaui oleh pancaindra responden. Sebanyak $81 \%$ responden menyatakan bahwa kualitas air yang mereka terima adalah baik (jernih dan tidak berbau) sehingga dapat digunakan untuk air minum dan memasak. Hanya sebanyak 9\% responden menyatakan kualitas air yang mereka terima tidak baik yaitu keruh dan adanya bau kaporit terutama pada musim hujan.

\subsection{Analisis keinginan membayar (WTP) pelanggan PLN dan PDAM}

Keinginan membayar (WTP) terhadap konservasi daerah tangkapan air didapatkan dengan cara bertanya langsung terhadap responden yaitu kepada pelanggan PLN di Pekanbaru dan PDAM Tirta Kampar di Kabupaten Kampar, serta kepada jajaran top management perusahaan PLN dan PDAM Tirta Kampar. Hal yang ditanyakan adalah mengenai besarnya uang yang ingin dibayarkan untuk upaya konservasi daerah tangkapan air. Pada kajian ini, responden diberikan pilihan antara bersedia membayar atau tidak bersedia membayar untuk upaya konservasi daerah tangkapan air.

Berdasarkan hasil kajian, sebanyak 73,5\% responden pelanggan PLN bersedia membayar dan $26,5 \%$ sisanya tidak bersedia. Sementara untuk responden PDAM, sebanyak 89\% responden bersedia membayar dan 11\% responden tidak bersedia (Gambar 4). Hal ini menunjukkan bahwa secara mayoritas, responden mempunyai kepedulian dan ingin berpartisipasi terhadap upaya konservasi daerah tangkapan air. 


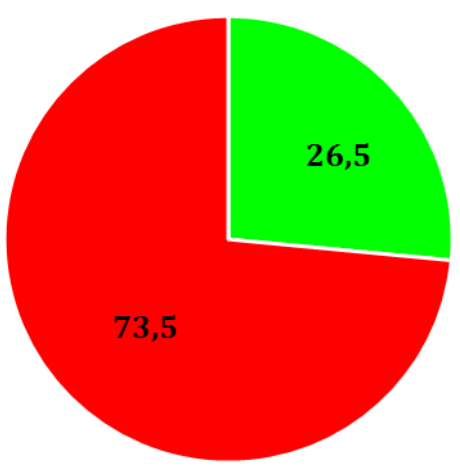

(a)

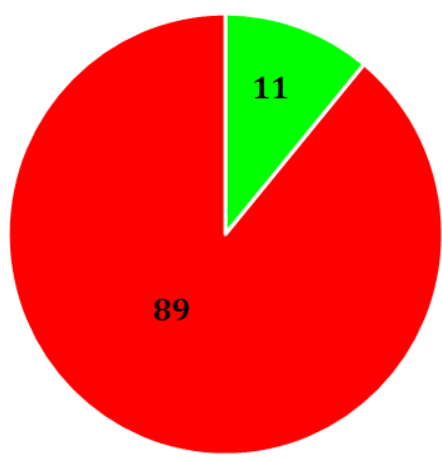

(b)

- : Tidak bersedia membayar

- : : Bersedia membayar

Gambar 4. Persentase kesediaan membayar program konservasi daerah tangkapan air ( $a=$ pelanggan PLN; $b=$ pelanggan PDAM).

Responden bersedia membayar upaya konservasi daerah tangkapan air didasari oleh beberapa alasan yaitu kesadaran bahwa konservasi daerah tangkapan air merupakan tanggung jawab bersama antara pemerintah dan masyarakat; kesadaran terhadap manfaat konservasi yakni untuk kepentingan bersama; dan kesadaran bahwa air merupakan kebutuhan pokok atau penting sehingga untuk mendapatkan kuantitas, kualitas dan kontinuitas air yang lebih baik, terjaga dan berkelanjutan perlu dilakukan upaya konservasi.

Berdasarkan alasan tersebut, terlihat bahwa secara umum responden telah memiliki persepsi bahwa pentingnya upaya konservasi daerah tangkapan air memerlukan biaya dan semua pemanfaat jasa lingkungan air perlu berpartisipasi. Keadaan ini juga memperlihatkan bahwa secara umum mayoritas responden mempunyai kepedulian yang tinggi terhadap upaya konservasi daerah tangkapan air dan upaya perbaikan lingkungan. Menurut Drakel (2008), besarnya tingkat kepedulian seseorang terhadap upaya perbaikan lingkungan akan mempengaruhi kesediaan mereka untuk membayar (nilai WTP). Hal ini sejalan dengan hasil penelitian Ayunanto (2008) yang menyatakan bahwa persepsi responden sangat mempengaruhi kesediaannya dalam memberikan atau membayar nilai WTP.

Beberapa alasan yang menyebabkan responden tidak bersedia membayar upaya konservasi daerah tangkapan air adalah kondisi keuangan responden yang tidak mendukung atau memadai, anggapan bahwa konservasi daerah tangkapan air merupakan tanggung jawab pemerintah, telah ada anggarannya dalam APBN/APBD, telah membayar biaya administrasi kepada PLN dan PDAM tiap bulan dan merasa tarif listrik dan air pun sudah mahal. Berdasarkan alasan tersebut terlihat bahwa meskipun responden tidak bersedia membayar upaya 
konservasi daerah tangkapan air, namun tetap mengharapkan tidak terganggunya pasokan listrik dan air. Hal ini terlihat dari alasan terbanyak tidak bersedianya membayar adalah dikarenakan alasan ekonomi atau kondisi keuangan responden tidak mendukung.

Nilai WTP pelanggan PLN terhadap konservasi daerah tangkapan air dianalisis dengan metode CVM. Sampel yang dianalisis adalah responden, baik yang memberikan jawaban bersedia membayar terhadap upaya konservasi daerah tangkapan air maupun yang tidak memberikan nilai WTP. Dari 200 responden yang diwawancarai terdapat 147 orang pelanggan $(73,5 \%)$ yang bersedia membayar konservasi daerah tangkapan air dan 53 orang pelanggan $(26,5 \%)$ tidak bersedia membayar (Tabel 2).

Nilai keinginan membayar dari pelanggan PLN bervariasi mulai dari Rp1.500/bulan sampai dengan Rp5.000/bulan, dengan nilai keinginan membayar (WTP) rata-rata sebesar Rp1.877/bulan. Adanya variasi nilai WTP yang diberikan oleh responden disebabkan oleh adanya perbedaan karakteristik sosial ekonomi responden dan perbedaan pengetahuan, penilaian dan sikap.

Tabel 2. Distribusi frekuensi nilai WTP pelanggan PLN.

\begin{tabular}{ccccr}
\hline No & Nilai WTP (Rp) & Frekuensi (f) & Persentase (\%) & WTP x f \\
\hline 1 & - & 53 & 26,5 & - \\
2 & 1.500 & 93 & 46,5 & 139.500 \\
3 & 2.000 & 37 & 18,5 & 74.000 \\
4 & 2.500 & 3 & 1,5 & 7.500 \\
5 & 3.000 & 6 & 3 & 18.000 \\
6 & 4.000 & 5 & 1,5 & 12.000 \\
7 & 5.000 & 200 & 2,5 & 25.000 \\
\hline & Jumlah & 100,00 & 276.000 \\
\hline & Rata-rata & & 1.877 \\
\hline
\end{tabular}

Sama halnya dengan pelanggan PLN, nilai keinginan membayar (WTP) pelanggan PDAM terhadap konservasi daerah tangkapan air juga dianalisis dengan metode CVM. Sampel yang dianalisis adalah responden baik yang memberikan jawaban bersedia membayar terhadap upaya konservasi daerah tangkapan air PDAM maupun yang tidak memberikan nilai WTP. Dari 100 responden yang diwawancarai terdapat 94 orang pelanggan (94\%) yang bersedia membayar konservasi daerah tangkapan air PDAM dan 6 orang pelanggan $(6 \%)$ tidak bersedia membayar.

Nilai keinginan membayar dari pelanggan PDAM bervariasi mulai dari Rp1.500/bulan sampai dengan Rp5.000/bulan, dengan nilai keinginan membayar (WTP) rata-rata sebesar Rp2.528/bulan (Tabel 3). Adanya variasi nilai WTP yang diberikan oleh responden disebabkan oleh adanya perbedaan karakteristik sosial ekonomi responden dan perbedaan pengetahuan, penilaian, sikap terhadap upaya konservasi sumber air baku dan persepsi terhadap 
kuantitas dan kualitas air yang diterima pelanggan. Menurut Jordan dan Elnagheeb dalam Zakiah (2009), WTP seseorang untuk memperoleh kualitas air bersih yang lebih baik dipengaruhi oleh pendapatan, umur kepala keluarga, tingkat pendidikan, persepsi terhadap kualitas air bersih yang sekarang dikonsumsi (baik atau tidak) dan ketidakpastian tentang kuantitas dan kualitas air bersih yang dikonsumsi.

Tabel 3. Distribusi frekuensi nilai WTP pelanggan PDAM.

\begin{tabular}{ccccr}
\hline No & Nilai WTP (Rp) & Frekuensi (f) & Persentase (\%) & WTP x f \\
\hline 1 & - & 11 & 11 & - \\
2 & 1.500 & 29 & 29 & 43.500 \\
3 & 2.000 & 26 & 26 & 52.000 \\
4 & 2.500 & 4 & 4 & 10.000 \\
5 & 3.000 & 14 & 14 & 42.000 \\
6 & 4.000 & 2 & 2 & 8.000 \\
7 & 4.500 & 1 & 1 & 4.500 \\
8 & 5.000 & 13 & 13 & 65.000 \\
\hline & Jumlah & 100 & & 225.000 \\
\hline & Rata-rata & &
\end{tabular}

Nilai dugaan rataan WTP pelanggan PLN didapatkan dari nilai mean (rataan) terhadap 200 responden. Jika dihitung nilai median dari 200 responden didapatkan nilai sebesar Rp1.500/KK/bulan. Sementara nilai dugaan rataan WTP pelanggan PDAM yang didapatkan dari nilai mean terhadap 100 responden. Jika dihitung nilai median dari 100 responden didapatkan nilai sebesar Rp2000/KK/bulan. Dalam kajian ini yang digunakan adalah nilai WTP berdasarkan nilai mean. Nilai mean, median dan standar deviasi dari variabel WTP, pendapatan, tagihan listrik dan air, serta jumlah tanggungan keluarga disajikan pada Tabel 4 dan Tabel 5.

Tabel 4. Hasil perhitungan statistik terhadap responden pelanggan PLN.

\begin{tabular}{clccc}
\hline No & Variabel & Mean & Median & Standar deviasi \\
\hline 1 & WTP (Rp) & 1.878 & 1.500 & 762,09 \\
2 & Pendapatan (Rp/bulan) & 3.141 .500 & 3.000 .000 & 1.766 .360 \\
3 & Tagihan Listrik (Rp/bulan) & 583.675 & 600.000 & 363.287 \\
4 & Jumlah Tanggungan Keluarga & 3 & 3 & 1,99 \\
& (orang) & & 3 & \\
\hline
\end{tabular}

Jika rata-rata nilai WTP pelanggan PLN adalah Rp1.878/bulan dan bila dibandingkan dengan kemampuan membayar pelanggan PLN yang dilihat dari rata-rata pendapatan per bulannya sebesar Rp3.141.500, maka nilai WTP yang diberikan tersebut tergolong sangat kecil. Nilai rata-rata WTP responden sebesar Rp1.878/bulan juga lebih kecil dari nilai rata-rata tagihan rekening listrik yang dibayarkan pelanggan setiap bulannya yakni sebesar Rp583.675/bulan. 
Tabel 5. Hasil perhitungan statistik terhadap responden pelanggan PDAM.

\begin{tabular}{clccc}
\hline No & Variabel & Mean & Median & Standar deviasi \\
\hline 1 & WTP (Rp) & 2.528 & 2.000 & $1.209,24$ \\
2 & Pendapatan (Rp/bulan) & 3.147 .000 & 3.000 .000 & 1.716 .554 \\
3 & Tagihan Listrik (Rp/bulan) & 100.093 & 69.055 & $83.751,29$ \\
4 & Jumlah Tanggungan Keluarga & 3 & 3 & 1,15 \\
\hline
\end{tabular}

Jika rata-rata nilai WTP pelanggan adalah Rp2.528/bulan dan dibandingkan dengan kemampuan membayar pelanggan PDAM yang dilihat dari rata-rata pendapatan per bulannya sebesar Rp3.147.000, maka nilai WTP yang diberikan tersebut tergolong sangat kecil. Nilai rata-rata WTP responden sebesar Rp2.528/bulan juga lebih kecil dari nilai rata-rata tagihan rekening air yang dibayarkan pelanggan setiap bulannya yakni sebesar Rp100.093/bulan.

Nilai keinginan membayar agregat atau WTP total (TWTP) adalah akumulasi dari nilai WTP sampel terhadap jumlah populasi, sehingga dihasilkan nilai total sesuai kondisi faktual. Tabel 6 menunjukkan bahwa dari 476.931 pelanggan PLN didapatkan nilai WTP total terhadap upaya konservasi daerah tangkapan air sebesar Rp895.462.286 per bulan atau sekitar Rp10.745.547.432 per tahun. Selanjutnya, Tabel 7 menunjukkan bahwa dari 6.829 pelanggan PDAM Tirta Kampar, didapatkan nilai WTP total terhadap upaya konservasi daerah tangkapan air adalah Rp16.919.039 per bulan atau sekitar Rp203.028.472 per tahun. Jika digabung antara WTP pelanggan PLN dan PDAM, maka didapatkan nilai sekitar Rp10.948.575.904 per tahun.

Tabel 6. Nilai WTP total pelanggan PLN.

\begin{tabular}{ccrrrrrr}
\hline No & $\begin{array}{c}\text { Nilai WTP } \\
\text { (Rp) }\end{array}$ & $\begin{array}{c}\text { Q } \\
\text { sampel }\end{array}$ & $\begin{array}{c}\text { \% Q } \\
\text { sampel }\end{array}$ & $\begin{array}{c}\text { \% Kumulatif } \\
\text { Q sampel }\end{array}$ & $\begin{array}{r}\text { Q } \\
\text { pelanggan }\end{array}$ & P*Q & \multirow{2}{*}{ WTP kumulatif } \\
\hline 1 & 1.500 & 93 & 63,27 & 63,27 & 301.732 & 452.597 .786 & 452.597 .786 \\
2 & 2.000 & 37 & 25,17 & 88,44 & 120.044 & 240.087 .714 & 692.685 .500 \\
3 & 2.500 & 3 & 2,04 & 90,48 & 9.733 & 24.333 .214 & 717.018 .714 \\
4 & 3.000 & 6 & 4,08 & 94,56 & 19.467 & 58.399 .714 & 775.418 .429 \\
5 & 4.000 & 3 & 2,04 & 96,60 & 9.733 & 38.933 .143 & 814.351 .571 \\
6 & 5.000 & 5 & 3,40 & 100,00 & 16.222 & 81.110 .714 & 895.462 .286 \\
\hline
\end{tabular}

Tabel 7. Nilai WTP total pelanggan PDAM.

\begin{tabular}{ccccccrr}
\hline No & $\begin{array}{c}\text { Nilai WTP } \\
(\mathrm{Rp})\end{array}$ & $\begin{array}{c}\mathrm{Q} \\
\text { sampel }\end{array}$ & $\begin{array}{c}\% \mathrm{Q} \\
\text { sampel }\end{array}$ & $\begin{array}{c}\text { \% Kumulatif } \\
\text { Q sampel }\end{array}$ & $\begin{array}{c}\mathrm{Q} \\
\text { pelanggan }\end{array}$ & $\mathrm{P}^{*} \mathrm{Q}$ & WTP kumulatif \\
\hline 1 & 1.500 & 29 & 33 & 33 & 2.225 & 3.337 .770 & 3.337 .770 \\
2 & 2.000 & 26 & 29 & 62 & 1.995 & 3.989 .978 & 7.327 .747 \\
3 & 2.500 & 4 & 4 & 66 & 307 & 767.303 & 8.095 .051 \\
4 & 3.000 & 14 & 16 & 82 & 1.074 & 3.222 .674 & 11.317 .725 \\
5 & 4.000 & 2 & 2 & 84 & 153 & 613.843 & 11.931 .567 \\
6 & 4.500 & 1 & 1 & 85 & 77 & 345.287 & 12.276 .854 \\
7 & 5.000 & 13 & 15 & 100 & 997 & 4.987 .472 & 16.919 .039 \\
\hline
\end{tabular}


Nilai keinginan membayar (WTP) total terhadap upaya konservasi daerah tangkapan air dari pelanggan PLN dan PDAM tersebut merupakan nilai estimasi kompensasi dana konservasi dari pemanfaat air untuk melindungi daerah tangkapan air. Bagi pelanggan PLN dan PDAM sebagai pemanfaat air, nilai kontribusi konservasi tersebut merupakan bentuk dari kontribusi hilir untuk membantu melestarikan kawasan daerah tangkapan air di bagian hulu. Estimasi dana konservasi yang berasal dari pemanfaat air tersebut bisa digunakan untuk membiayai upaya rehabilitasi dan konservasi daerah tangkapan yang sekarang kondisinya sudah banyak yang kritis.

Keinginan menerima (WTA) terhadap konservasi daerah tangkapan air didapatkan dengan cara bertanya langsung terhadap responden di daerah tangkapan air di Kabupaten Lima Puluh Kota, Provinsi Sumatera Barat mengenai besarnya uang yang diperlukan untuk upaya konservasi daerah tangkapan air. Dalam kajian ini, responden diberikan pertanyaan mengenai persetujuan mereka terhadap upaya konservasi daerah tangkapan air melalui skema jasa lingkungan. Semua responden menyatakan setuju terhadap skema jasa lingkungan dan bersedia pula mengikuti program konservasi daerah tangkapan air melalui skema jasa lingkungan. Persentase luasan rata-rata lahan responden yang akan diikutsertakan dalam jasa lingkungan dapat dilihat pada Gambar 5. Saat ini, komoditas yang diusahakan pada lahan-lahan tersebut meliputi cabai, cengkeh, durian, gambir, karet, limau, manggis, padi, pinang, pinus dan sawit.

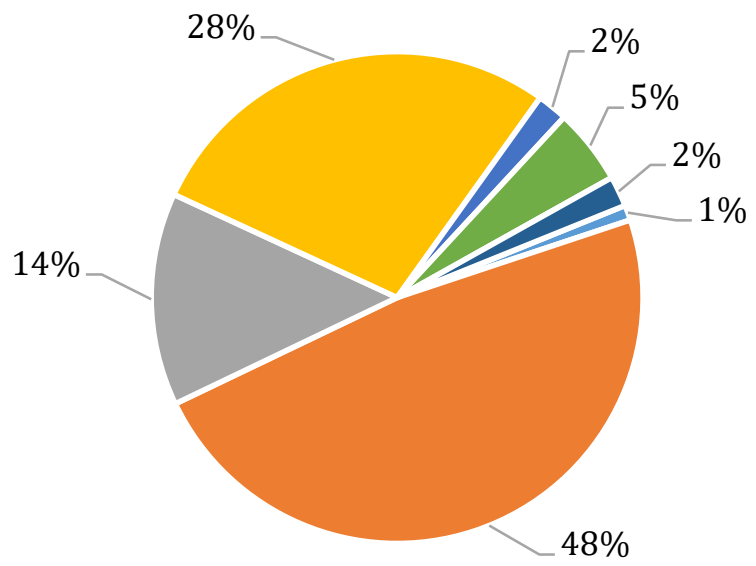

$$
\begin{aligned}
& -0,5 \text { ha } \\
& -1 \text { ha } \\
& -1,5 \text { ha } \\
& -2 \text { ha } \\
& -2,5 \text { ha } \\
& -3 \text { ha } \\
& -4 \text { ha }
\end{aligned}
$$

Gambar 5. Persentase luasan rata-rata lahan responden yang ikut serta dalam upaya konservasi daerah tangkapan air.

Keinginan responden untuk terlibat dalam upaya konservasi daerah tangkapan air didasari oleh beberapa alasan yaitu kesadaran bahwa konservasi daerah tangkapan air merupakan tanggung jawab bersama antara pemerintah dan masyarakat; kesadaran terhadap manfaat konservasi yakni untuk 
kepentingan bersama; dan kesadaran bahwa air merupakan kebutuhan pokok atau penting sehingga untuk mendapatkan kuantitas, kualitas dan kontinuitas air yang lebih baik, terjaga dan berkelanjutan perlu dilakukan upaya konservasi.

Nilai keinginan menerima (WTA) didapatkan dengan memberikan pilihan biaya kepada responden. Nilai yang didapatkan sudah dianggap mencukupi untuk pembiayaan konservasi daerah tangkapan air, yaitu penanaman dan pemeliharaan pohon. Nilai keinginan menerima (WTA) responden adalah Rp5.900/pohon/tahun.

Nilai WTP pemanfaat air sebesar Rp10.948.575.904 per tahun dapat digunakan untuk kegiatan konservasi secara vegetatif dan sipil teknis. Berdasarkan PerDirJen PDASHL Nomor P.8 Tahun 2017 tentang Harga Satuan Pokok Kegiatan Bidang Pengendalian DAS dan Hutan Lindung Tahun 2018, biaya pembuatan tanaman reboisasi/rehabilitasi adalah Rp13.375.000 per ha mulai dari persiapan sampai dengan pelaksanaan di lapangan. Jika tersedia nilai WTP konservasi daerah tangkapan air sebesar Rp10.948.575.904 per tahun dari pemanfaat air, biaya konservasi ini dapat digunakan untuk merehabilitasi lahan kritis seluas 818,58 ha per tahun di daerah tangkapan air Koto Panjang. Jika dikaitkan dengan nilai WTA, maka biaya konservasi ini dapat digunakan untuk menanam 1.855.690 pohon per tahun. Biaya konservasi yang berasal dari nilai WTP pemanfaat air di DAS Kampar diharapkan akan mempercepat upaya rehabilitasi lahan kritis yang merupakan daerah tangkapan air penting.

\section{KESIMPULAN DAN SARAN}

\subsection{Kesimpulan}

Nilai keinginan membayar (WTP) dari pelanggan PLN adalah sebesar Rp895.462.286 per bulan atau sekitar Rp10.745.547.432 per tahun, sedangkan WTP dari pelanggan PDAM adalah sebesar Rp16.919.039 per bulan atau sekitar Rp203.028.472 per tahun. Nilai WTP total adalah Rp10.948.575.904 per tahun. Terdapat 7 variabel yang diduga berpengaruh terhadap keinginan membayar yaitu pendapatan, jumlah tanggungan, tagihan listrik dan air, jenis kelamin, pengetahuan tentang konservasi, pendidikan, persepsi tentang konservasi. Variabel pendapatan sangat berpengaruh terhadap konservasi daerah tangkapan air.

Nilai keinginan menerima (WTA) responden adalah sebesar Rp5.900/pohon/tahun. Nilai ini sudah dianggap mencukupi untuk pembiayaan konservasi daerah tangkapan air yang terdiri dari penanaman dan pemeliharaan pohon. Nilai WTP pemanfaat air sebesar Rp10.948.575.904 per tahun dapat digunakan untuk kegiatan konservasi secara vegetatif dan sipil teknis. Nilai WTP ini dapat digunakan untuk merehabilitasi lahan kritis seluas 818,58 ha per tahun atau untuk menanam 1.855 .690 pohon per tahun. 


\subsection{Saran}

Komunikasi dan koordinasi antar pemangku kepentingan dan antar daerah harus semakin giat dilaksanakan, dalam hal ini harus ada pihak yang mengambil peran sebagai fasilitator. Perlu dilakukan identifikasi terhadap pemanfaat air potensial lainnya walaupun dalam konteks lokal.

\section{DAFTAR PUSTAKA}

Ayunanto T. 2008. Pengaruh persepsi terhadap willingness to pay pengelolaan sampah rumah tangga Kota Cilacap [Tesis]. Program Pascasarjana, Universitas Padjadjaran. Bandung.

[BWSS III] Balai Wilayah Sungai Sumatera III. 2007. Laporan akhir penyusunan pola pengelolaan sumber daya air wilayah Sungai Kampar. BWSS III. Pekanbaru.

Drakel A. 2008. Analisis kemauan membayar masyarakat perkotaan untuk jasa perbaikan lingkungan, lahan dan air [Tesis]. Sekolah Pascasarjana, Institut Pertanian Bogor. Bogor.

Fauzi A. 2010. Ekonomi sumberdaya alam dan lingkungan: teori dan aplikasi. Penerbit PT Gramedia Pustaka Utama. Jakarta.

Fripp E. 2014. Payments for ecosystem services (PES): a practical guide to assessing the feasibility of PES projects. Center for International Forestry Research (CIFOR). Bogor.

Grizetti B, Lanzanova D, Liquete C, Reynaud A and Cardoso AC. 2016. Assessing water ecosystem services for water resource management. Environmental Science \& Policy 61(2016):194-203.

[Kementerian PUPR] Kementerian Pekerjaan Umum dan Perumahan Rakyat. 2015. Pola pengelolaan sumber daya air wilayah Sungai Kampar. Kementerian PUPR. Jakarta.

Kusuma DW. 2018. Tinjauan imbal jasa lingkungan pada daerah aliran sungai (DAS) Kampar Hulu (studi kasus di Kecamatan Bukit Barisan, Kabupaten Limapuluh Kota) [Prosiding]. Prosiding Seminar Nasional PIT ke-5 Riset Kebencanaan IABI 679-694.

PerDirJen PDASHL (Peraturan Direktur Jenderal Pengendalian DAS dan Hutan Lindung) Nomor P.8 Tahun 2017 tentang harga satuan pokok kegiatan bidang pengendalian DAS dan hutan lindung tahun 2018.

Pour MT, Kalashami and Kavoosi K. 2012. Applying CVM for economic valuation of drinking water in Iran. International Journal of Agricultural Management \& Development 2(3):209-214.

Zakiah YH. 2009. Analisis willingness to pay pelanggan PDAM terhadap konservasi sumber air baku PDAM (studi kasus di Kota Bandung) [Tesis]. Program Pascasarjana, Universitas Padjadjaran. Bandung. 